\title{
ON THE STRUCTURE, BIOLOGY AND SYSTEMATIC POSITION OF PHARUS LEGUMEN (L.)
}

\author{
By C. M. Yonge, D.Sc., F.R.S. \\ University of Glasgow
}

(Text-Figs. I-7)

The species with which this paper deals was originally included by Linné in the genus Solen and was there retained to be included under that name in the magnificently illustrated account of this genus by Deshayes (1845-48). It was later placed in a new genus Ceratisolen by Forbes \& Hanley (I853) who considered that it formed 'the connecting link between the Solenidae and Solecurtidae'. This procedure was followed by Jeffreys (1865). More recently the Solecurtidae were shown by Graham (1934b) having 'regard to such features as shape, presence of a cruciform muscle and the structure of the foot, siphons, adductor and pedal muscles, supra-axial extension of the outer demibranch, palps, and style-sac and intestine', to belong to the Tellinacea, a view fully supported by this author (Yonge, 1949). Assigned later to the genus Pharus which has priority over Ceratisolen, this 'connecting link' of Forbes \& Hanley continued to be associated with the Solenacea by Thiele (1935) in his great systematic account of the Mollusca.

Personal observations on the Tellinacea (Yonge, 1949) and later on Siliqua patula and other members of the Solenacea (Yonge, 1952) have indicated that Pharus legumen should also be transferred to the Tellinacea. This paper is primarily concerned with the reasons for this change in classification, and this has involved some description of structure and habits in this little known member of the British marine fauna. Nothing can supersede the magnificent plates in Deshayes (1845-48) but his account, although detailed, is not, by present standards, critical, while the very short description by Bloomer (1903) is of little value.

This work has been made possible largely through the kindness of Prof. E. W. Knight-Jones who, from Anglesey and later from the Swansea area, sent living specimens with information about the conditions under which they were found. Preserved specimens from Brittany were also kindly supplied by $\mathrm{Mr} \mathrm{N}$. A. Holme of the Plymouth Laboratory, while Prof. A. Graham and Dr V. Fretter of Reading have supplied preserved specimens and given information about habitat. Acknowledgements are also due to Dr H. F. Steedman and Dr G. Owen of this Department for technical help and also, in the case of Dr Owen, who is investigating allied problems, for much profitable discussion. 


\section{EXTERNAL APPEARANCE AND SHELL}

As Deshayes and other early workers pointed out, P. legumen (Fig. I) may be distinguished from other species of 'Solen' by the situation of the ligament, in the middle instead of at the anterior end of the long flat dorsal surface of the shell. There is also greater lateral compression of the shell than in species of Ensis or Solen while the valves taper somewhat anteriorly (in his figure of the shell with foot and siphons projecting, Jeffreys (I865) shows this the wrong way round). The shell attains a length of up to some $10 \mathrm{~cm}$ and is about four times longer than it is deep. It is pale yellow and glossy with a characteristic difference in texture and with a paler colour over the posterior sector (indicated in Fig. I). Hinge dentition, which may here be mentioned, consists of two cardinals in the left valve (see Fig. 2) and one on the right with, in each valve, a long and low anterior lateral and a short, projecting posterior lateral. There is nothing here of value in determining the systematic position of Pharus.

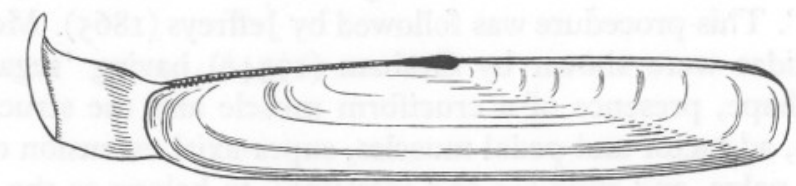

Fig. I. Pharus legumen, viewed from left with foot partly extended. $\times \frac{3}{4}$.

The elongated and very compressed foot (Figs. I, 2 and 4) issues through a restricted anterior gape. It is truncated terminally and when observed in a bowl of water makes very sudden extensions to a length as great as that of the shell, at the same time opening out terminally. It is then as quickly withdrawn. It is clearly fully as effective in rapid vertical burrowing as the foot of Ensis or Solen, described by Fraenkel (1927), but it differs in being less bulbous terminally. Siphons longer than those of species of Solen or Ensis (although shorter than those of Siliqua patula (Yonge, 1952)) project posteriorly and to a length of $5 \mathrm{~mm}$ in an animal of shell length $3.9 \mathrm{~cm}$. But, unlike all true members of the Solenacea, the inhalant and exhalant siphons are separate throughout (see Fig. 2) and are also, as shown later, fundamentally different in structure, a fact which initially indicated the affinity of this species to the Tellinacea.

Although first recognized as a British species by Martin Lister in the seventeenth century, Pharus legumen is relatively seldom encountered. It is a southern species (hence its description by Deshayes in an account of the marine molluscs of Algeria) and is here near the northern end of its range. It appears to be confined to the western end of the south coast, to the north coasts of Devon and Cornwall, to the shores of Wales and to all but the north coast of Ireland. It is not recorded from the Isle of Man or from the Clyde 
Sea Area. It ranges in the south from Brittany, around the shores of Spain and Portugal into the Mediterranean where it appears to be common. In Great Britain it is certainly only abundant around the shores of Wales and there, judging from information received from Prof. Knight-Jones, is commoner along the south coast than around Anglesey. It lives in relatively clean sand, although with some admixture of organic silt. To quote from a letter from Prof. Knight-Jones dealing with the Swansea area: 'The sand at Oxwich Bay where Pharus occurs near here is fine and fairly clean. The water above it is generally very turbid and there is a lot of silt washing about on the surface of the sand.' At Roscoff (I95I) it is stated as occurring 'A très basse mer, dans du sable plus ou moins pur'. It appears to inhabit a restricted zone on the margin of the lower shore and in the shallow sublittoral. Hence it can only be dug at low water of the greater spring tides while its capacity for rapid vertical burrowing makes it difficult to obtain by dredging which in any case is never easy in very shallow water. These restrictions, both in horizontal and vertical distribution around the shores of Great Britain, go far to explain the prevailing ignorance about this species.

\section{PALLIAL STRUCTURES}

Muscles. As shown in Fig. 2, the pallial (orbicular) muscles are attached at some distance from the margin of the shell. Both adductors, the anterior being much the longer, are extended longitudinally. The posterior adductor $(P A)$, as recently indicated by Owen (1958) in work concerned partly with the Solenacea, does not represent the termination of the pallial muscles at that end. For functional reasons, as in the Solenacea and in other bivalves where the shell has elongated, the region of local muscular hypertrophy represented by the adductor has migrated posteriorly but pallial attachment continues, as indicated in Fig. 2, up to the posterior end of the ligament. The shell is strengthened in the region of the hinge by a ventrally extending rib, the anterior surface of which bounds the posterior margin of attachment of the anterior adductor. Such strengthening of a relatively delicate extended shell is not unusual, occurring also in Siliqua patula. It has certainly no systematic value. The siphonal retractors are well developed and the pallial sinus is correspondingly capacious.

Mantle folds and fusion. The mantle margins are united along the greater part of the ventral surface and, except for the openings of the siphons, posteriorly right round to the posterior end of the ligament. Fusion is of Type B (Yonge, 1957), i.e. of inner (muscular) folds of the mantle edge together with the inner surfaces of the middle lobes. The outer surfaces of the middle lobes form a narrow ridge $(M F)$ between the outer lobes the innermost margin of which constitutes the periostracal groove (Fig. 3). The outer lobes are broad with periostracum extending for some distance within the 


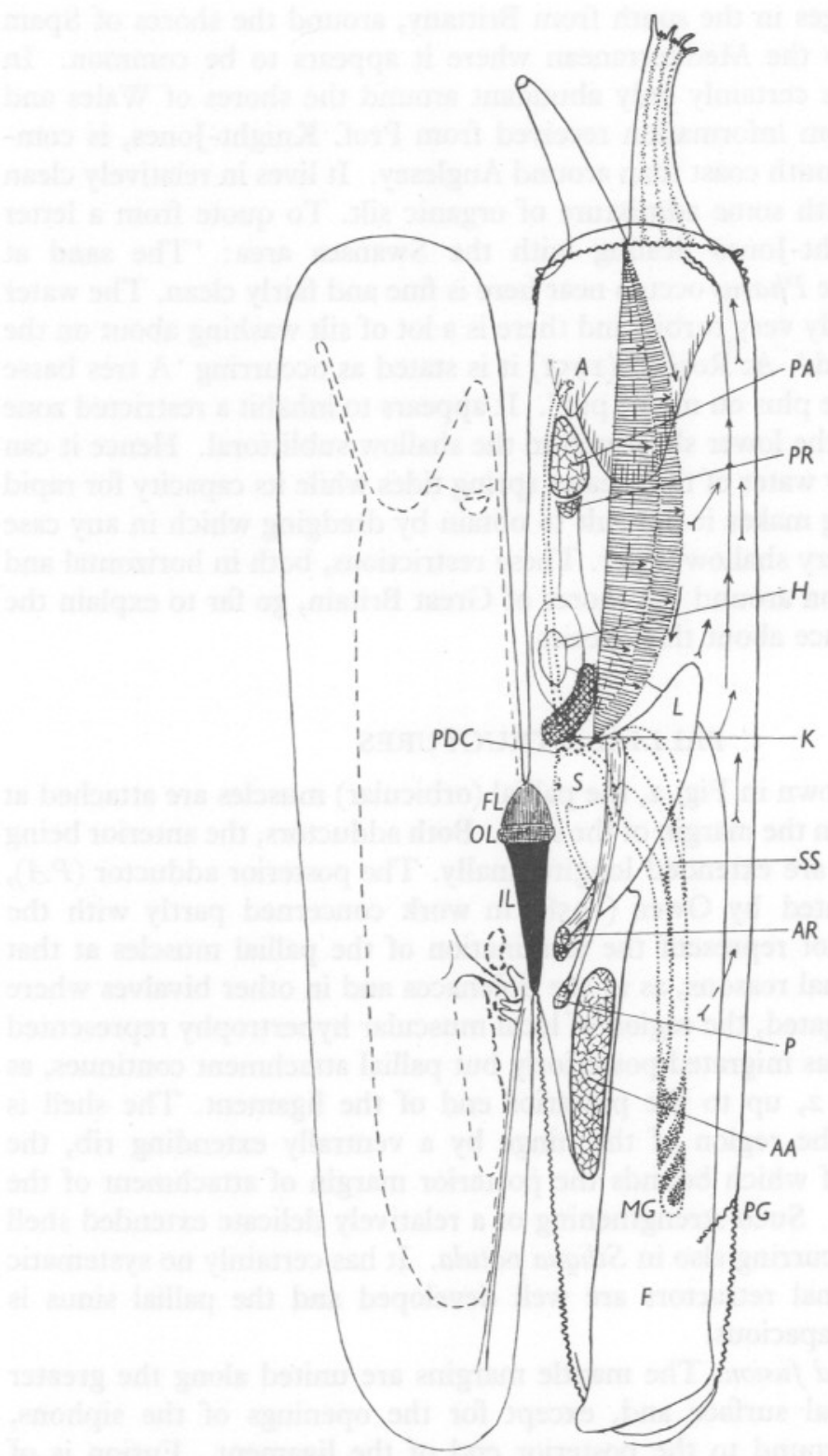

Fig. 2. Pharus legumen, animal lying in right valve with siphons extended, left valve turned back to show ligament, hinge teeth and muscle insertions (indicated by broken lines). $\times \mathrm{I} \frac{1}{2}$. $A$, anus; $A A$, anterior adductor; $A R$, anterior pedal retractor; $F$, foot; $F L$, fusion layer of ligament; $H$, heart; $I L$, inner layer of ligament; $K$, kidney; $L$, labial palp; $M G$, coiled region of mid-gut extending into foot; $O L$, outer layer of ligament; $P$, pedal protractor; $P A$, posterior adductor; $P D C$, postero-dorsal caecum of stomach; $P G$, posterior end of pedal gape; $P R$, posterior pedal retractor; $S$, Stomach; $S S$, style-sac. Plain arrows indicate direction of food collecting currents, feathered arrows of rejection currents. 
margin of the outer calcareous layer of the shell which is secreted by the outer surface of the outer fold (Yonge, 1957). On the dorsal surface anterior to the ligament, the middle mantle folds are nowhere united, their free margins being bounded by short tentacles as indicated in Figs. I and 2. But formation and anterior extension of the anterior adductor does represent extensive fusion of the inner mantle folds in this region. It should be noted that there is no cuticular fusion of the anterior regions of the mantle margins ventrally which is so characteristic a feature in the Solenacea where it occurs in Solen, Ensis and Cultellus; previously overlooked in Siliqua patula (Yonge, 1952), it has been found there by Owen (1959).

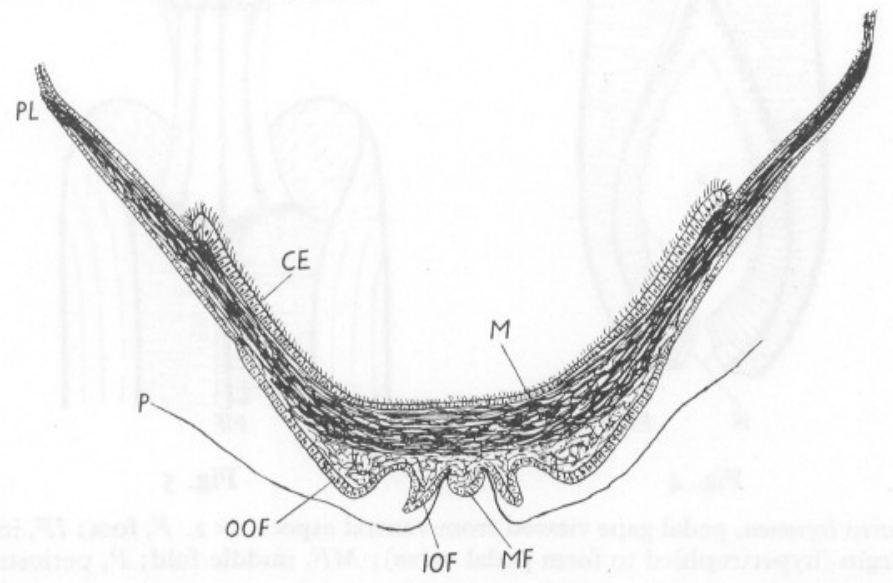

Fig. 3. Pharus legumen, transverse section through fused, mid-ventral region of mantle lobes posterior to palps (see Fig. 2). $\times 90 . C E$, ciliated epithelium; $I O F$, inner surface of outer fold of mantle margin (secretes periostracum); $M$, pallial muscle; $M F$, fused middle mantle folds; $O O F$, outer surface of outer mantle fold (secretes outer calcareous layer of shell); $P$, periostracum (other shell layers not shown); $P L$, pallial line.

The pedal gape extends from the anterior end of the ligament dorsally to a point some one-fifth of the distance back along the ventral surface. The single row of tentacles which fringe the middle mantle fold is well developed both ventrally and dorsally but anteriorly the tentacles are reduced over an area where the inner mantle folds $(I F)$ increase greatly in depth and become frilled (Fig. 4). They form a pedal valve resembling that found in Solenacea such as Ensis and having presumably the same function, namely wiping the surface of the foot as it is being withdrawn.

Siphons. Separate to the base, these are formed exclusively from the inner folds of the mantle margin. The small middle folds with the adjacent periostracal groove (this representing the innermost margin of the outer fold) extend, as shown in Figs. 2 and 5, around the base of the siphons, uniting above and below. The exhalant siphon bears no marginal tentacles and curves slightly dorsalwards; the inhalant siphon is fringed with a series of eight large 
and sixteen very small tentacles, the latter arranged in pairs between the larger ones. The surface of this siphon carries eight pigmented lines which run to each of the pairs of small tentacles. In their complete separation and formation exclusively from inner mantle folds, these siphons are identical with those of the Tellinacea; siphons in the Solenacea are largely united, the common outer covering with its tentacles being formed from the middle

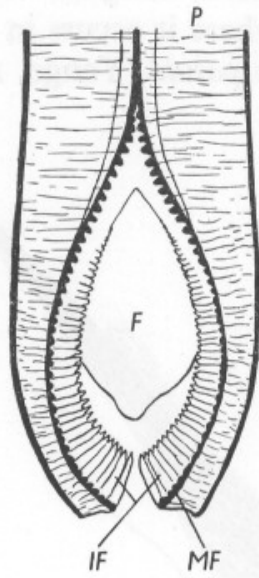

Fig. 4

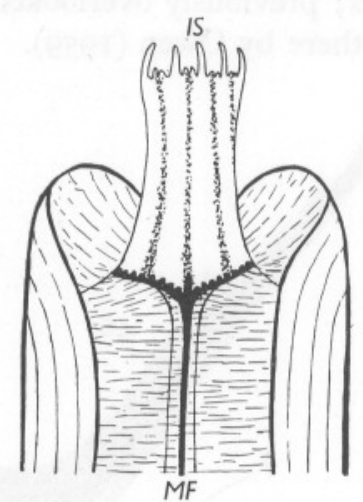

Fig. 5

Fig. 4. Pharus legumen, pedal gape viewed from ventral aspect. $\times 2 . F$, foot; $I F$, inner fold of mantle margin (hypertrophied to form pedal valve); $M F$, middle fold; $P$, periostracum.

Fig. 5. Pharus legumen, posterior end of shell with inhalant siphon viewed from ventral aspect. $\times 2$. $I S$, inhalant siphon; $M F$, middle fold of mantle margin.

mantle folds. Furthermore, in transverse section (Fig. 6), the siphons of $P$. legumen reveal the highly characteristic structure of the siphons of the Tellinacea as described and figured by Rawitz (1892), Hoffmann (I9I4), Graham (1934b), Yonge (1949) and Chapman \& Newell (1956). Between the inner and the outer epithelia there lie alternating circular layers of collagen fibres $\left(C_{1}-C_{4}\right)$-originally described by all workers as circular muscle fibres but correctly interpreted by Chapman \& Newell-and bundles of longitudinal muscle $\left(L_{1}-L_{3}\right)$. There are four layers of the former and three of the latter, the outermost of these muscle layers being poorly developed. Radiating strands $(R)$ of probably mixed muscle and collagen fibres traverse these concentric layers. In the zone occupied by the innermost muscle layer run the symmetrically disposed nerves $(N)$, four in the exhalant and eight in the inhalant siphon. Haemocoels $(H)$ occur on the inner side of the middle of the three muscle layers.

The entire picture is precisely that seen in cross-sections through the siphons of species of such characteristic genera of the Tellinacea as Tellina, 
Macoma, Abra, Scrobicularia, Donax, Gari and Solecurtus (Yonge, 1949). Only in the number of nerves is there some difference, this being six in species of all of the above genera where the inhalant siphon bears that number of fringing lobes. Rawitz, however, found that there were occasionally eight nerves in Gari depressa (presumably in association with that number of marginal lobes), while in Tagelus dombeyi the number is normally eight (Hoffmann, I9I4). In the Solenacea the histological picture is completely different. Longitudinal, circular and radial muscles are all well developed but apart from a tendency (noted in sections of both Ensis and Solen) for longitudinal muscle to be most developed under the outer and inner epithelia,

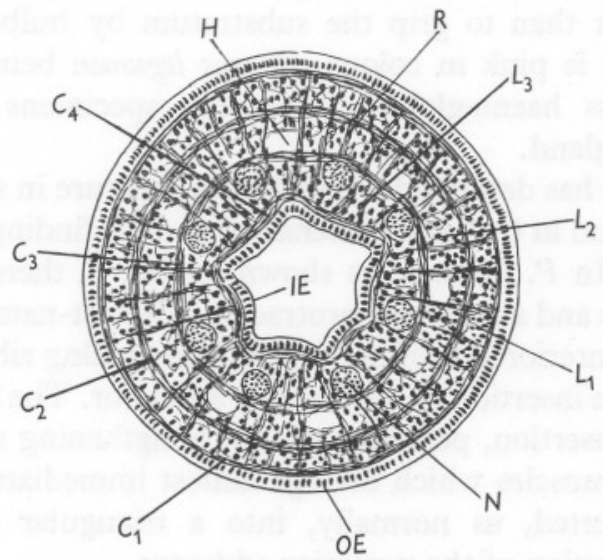

Fig. 6. Pharus legumen, transverse section through inhalant siphon. $\times 90 . C_{1}-C_{4}$, circular layers of collagen fibres; $H$, haemocoel; $I E$, epithelium lining cavity of siphon; $L_{1}-L_{3}$, layers of longitudinal muscle; $N$, nerve (one of eight); $O E$, epithelium of outer surface of siphon; $R$, radial muscle.

there is no trace of the organization into sharply defined zones so highly characteristic of the Tellinacea and associated, as demonstrated by Chapman \& Newell, with an intrinsic and highly effective mechanism of extension and withdrawal.

Ligament. This requires little comment; it was not considered necessary to examine or describe it in detail. It is opisthodetic, elongate and external (Fig. I). There is a long inner ligament layer secreted by the mantle isthmus where the epithelial cells are notably lengthened. Posterior to this is a broader but narrow region where the outer ligament layer is formed (anterior secretion of this layer is necessarily slight) and behind this again a broad fusion layer. This extends back under the level of the calcareous substance of the valves with which it becomes incorporated. These three major regions are indicated in Fig. 2. Conditions are thus essentially similar to those described in detail (although with superseded terminology) for Tellina tenuis by Trueman (I949) 
and more generally for Scrobicularia plana and Abra alba (Trueman, 1953). The only differences in Pharus are the greater length of the ligament and its greater secondary attachment, by way of the fusion layer posteriorly, to the shell valves.

\section{ORGANS IN THE MANTLE CAVITY}

Foot and pedal muscles. The size of the foot has already been noted, even when fully contracted it is some half the length of the shell. Although obviously resembling that of the Solenidae in general form, to some extent it differs slightly from that organ and resembles the foot of the Tellinacea in the presence of a more defined and rather frilled lateral margin. In action it tends to open out rather than to grip the substratum by bulbous dilation as in Ensis or Solen. It is pink in colour, Pharus legumen being one of the few bivalves to possess haemoglobin. In young specimens there is a welldeveloped byssus gland.

Graham $(1934 b)$ has described the pedal musculature in a variety of species of the Tellinacea and in Cultellus (Solenacea) and his findings have been helpful in this work. In P. legumen, as shown in Fig. 2, there are anterior and posterior retractors and an anterior protractor. The last-named is inserted into the valves on the anterior side of the ventrally extending rib and dorsal to the posterior end of the insertion of the anterior adductor. The anterior retractors have one area of insertion, posterior to the strengthening shell rib, although consisting of two muscles which diverge almost immediately. The posterior retractors are inserted, as normally, into a triangular area immediately anterior to the insertion of the posterior adductor.

The anterior retractor has a single insertion as it does in the Tellinacea but this cannot be considered of systematic value because although there is usually a double insertion of this muscle in the Solenacae, in Solen, as recently shown by Owen (1959) it is single. However, conditions in Pharus do certainly resemble those in the Tellinacea the only difference being that the muscle usually divides further from the point of insertion than it does in P. legumen. In this species also the anterior retractors are the most internal of the extrinsic muscles of the foot whereas the opposite is the case in Cultellus (Graham, $1934 b$ ). But, despite earlier views to the contrary, this also has no systematic value, conditions varying greatly within the Solenacea as shown by Owen (I959).

Palps and Ctenidia. The palps are large, there being no such long proximal oral groove between them and the mouth as there is in Solenacea such as Ensis siliqua (Graham, 1934) or E. arcuatus (Yonge, 1952). They are muchridged on the opposed faces and are clearly most efficient organs of selection.

With reference to the ctenidia, Ridewood (I903) states that, 'Ceratisolen (i.e. Pharus) legumen has a non-plicate, homorhabdic gill, in striking contrast with those of other genera of the Solenidae'. However, the ctenidia of 
Cultellus, undoubtedly a member of that family, are homorhabdic (Atkins, 1936) while in the Tellinacea, the ctenidia are homorhabdic in Tellina, Macoma, Scrobicularia, Abra and in Donax vittatus (Atkins, 1937a), although Ridewood (I903) found a variety of conditions in different species of Donax, some being homorhabdic and others heterorhabdic. In all species of Gari and Solecurtus examined by Ridewood (1903) and Atkins (1937a), the ctenidia were plicate, i.e. heterorhabdic.

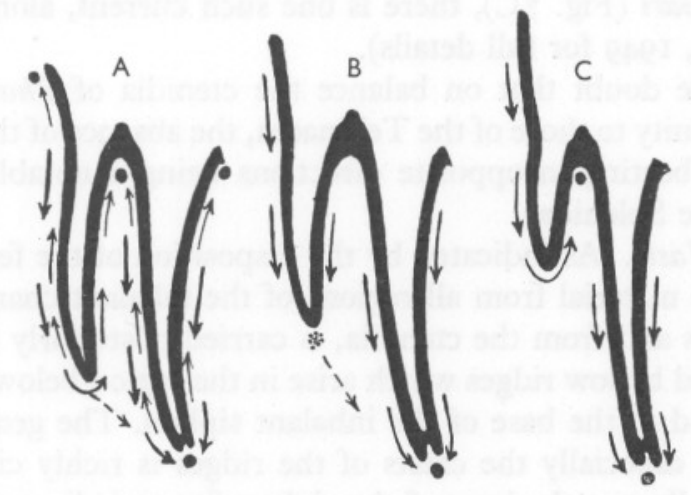

Fig. 7. Diagrams showing arrangement of ciliary currents on ctenidia of A, Cultellus pellucidus; B, Pharus legumen; C, Donax vittatus or Gari spp. (A and C after Yonge, 1949.)

A further point is the well-marked supra-axial extension of the outer lamellae of the outer demibranch. This is shown in Fig. $7 \mathrm{~B}$ and the same condition is found very generally throughout the Tellinacea (Yonge, 1949, Fig. 22) where indeed it is much further developed in the Tellinidae (e.g. Tellina, Macoma) and Semelidae (e.g. Scrobicularia, Abra). Conditions in Donax, Gari (Fig. 7 C) or Solecurtus most resemble those in Pharus. However, a slight supra-axial extension does also occur in Cultellus (Fig. $7 \mathrm{~A}$ ) and is well developed in a wide variety of other Eulamellibranchia. There remains for final consideration the ciliation. Here a real difference exists. In all Solenidae studied, i.e. Ensis, Solen, Cultellus (Atkins, 1936, I937a) and Siliqua (Yonge, I952), the ordinary filaments (in Cultellus, which is homorhabdic this means all filaments) bear both large and small frontal cilia (Fig. 7A). The former beat towards the free margins of the demibranchs and the latter in the opposite direction, i.e. towards the axis or the outer extremities of the demibranchs. The effect is to select the finer particles for conveyance oralwards along these three dorsal channels while the larger particles are conveyed to the marginal (so-called 'food') groove on the inner demibranch from which the greater part will fall off on to the mantle surface and be removed with the pseudofaeces.

In Pharus legumen (Fig. 7 B) there are no small frontal cilia, all cilia beating marginally. There is a resemblance to the foregoing conditions in the presence of a marginal groove on the inner demibranch only but this is also true of all 
Tellinacea (e.g. Donax or Gari as shown in Fig. 7 C). The margin of the outer demibranch, however, bears a series of coarse marginal cilia precisely as described and figured in that region in Gari fervensis by Atkins (1937 b, fig. 8). Also significant is the absence in Pharus legumen of any dorsal oralward current, conditions here differing from those in the Solenacea with three such dorsal currents (see Fig. $7 \mathrm{~A}$ ) and resembling those in the Tellinacea where in some species there are no such currents while in others, including species of Donax and Gari (Fig. $7 \mathrm{C}$ ), there is one such current, along the ctenidial axis (see Yonge, 1949 for full details).

There is little doubt that on balance the ctenidia of Pharus legumen do reveal closer affinity to those of the Tellinacea, the absence of the double series of frontal cilia beating in opposite directions being a notable point of difference from the Solenidae.

Disposal of Waste. As indicated by the disposition of the feathered arrows in Fig. 2, waste material from all regions of the inhalant chamber, from the tips of the palps and from the ctenidia, is carried posteriorly along a ventral channel bounded by low ridges which arise in the region below the tips of the palps and extend to the base of the inhalant siphon. The general surface of this region and especially the crests of the ridges is richly ciliated (Fig. 3). Pseudofaeces collect at the base of the siphon for periodic expulsion. Much deeper ridges, better termed membranes, occur in Siliqua patula (Yonge, 1952) amongst the Solenacea and also in many Tellinacea (Yonge, I949), although not in Donax, Gari or Solecurtus. Certainly no systematic value can be placed on this structural feature of obvious functional convenience.

\section{ALIMENTARY CANAL}

The general course of the gut in Pharus legumen is shown in dotted outline in Fig. 2. There is an unusually long oesophagus, the stomach is extended somewhat dorso-ventrally, the mid-gut is separated from the long style-sac, extending alongside and then for some distance beyond this well forward into the foot. It is thrown terminally into a series of tight coils $(M G)$. It returns to pass dorsally to the right of the stomach and so, through the ventricle, to open at the anus behind the posterior adductor. The stomach easily dissects out in fresh material: it has a well-developed muscular wall with the contents, including sizable sand grains, in some degree of tension. There is a small postero-dorsal caecum (PDC), much as in Solecurtus (Yonge, 1949). The style is extremely stout and bears against a conspicuous gastric shield with a conspicuous tooth.

Significant matters are the character of the stomach and the deep penetration into the foot by the style-sac $(S S)$ and mid-gut $(M G)$. The stomach in the Tellinacea is highly characteristic having, in association with the deposit feeding habit, acquired many of the characteristics of a gizzard. These include 
an unusually stout style, very extensive gastric shield, muscular walls and a conspicuous postero-dorsal caecum peculiar to the group and apparently serving as a safety valve wherein excess particles are temporarily stored prior to trituration between style and gastric shield (Yonge, 1949). All of these features are present in Pharus, though not to so marked an extent as in genera such as Tellina and Scrobicularia. There is no resemblance to the stomach of the suspension feeding Solenacea. Although in Pharus, as in the Solenacea, style-sac and mid-gut are separate whereas they are united in the majority of the Tellinacea, this is not a feature of any phylogenetic significance and indeed the two are separate in Donax which certainly belongs to the Tellinacea. Deep penetration of the foot by style-sac and mid-gut does not occur in the Solenacea (Graham, 1931, 1934b; Owen, 1959).

\section{SYSTEMATIC POSITION}

Confining this discussion to essentials, of the various features discussed in this account of $P$. legumen the following may be regarded, from the standpoint of its affinities, as crucial:

Siphons. Their complete separation and formation exclusively from the inner folds of the mantle margin being ringed (inhalant siphon only) with a single row of simple tentacles; their complex internal structure of the type highly characteristic of the Tellinacea.

Ctenidia. Supra-axial extension but much more significant the absence of any dorsal oralward current and especially lack of the small frontal cilia and so of the mode of selection of particles on the gill surface so characteristic of the Solenacea.

Gut. General form of the stomach, especially the presence of a small postero-dorsal caecum found only in the Tellinacea; deep penetration of the mid-gut and style-sac into the foot, unlike the Solenacea.

No other character mentioned is entirely confined to the one group or the other but the above list provides sure grounds for the removal of Pharus from the Solenacea and its inclusion in the Tellinacea.

The major difference from the more obviously typical members of the Tellinacea is the absence of a cruciform muscle (Graham, r934a; Yonge, 1949). But this is also true of Novaculina and Sinovacula (subfamily Novaculininae) which, it has previously been suggested (Yonge, I949), should be removed from the family Solenidae where they were placed by Ghosh (I920) and transferred to the Tellinacea. This was on the basis of the formation of the siphons, unquestionably a crucial character because one not liable to adaptive modification. There is much greater supporting evidence for this transfer in the case of Pharus where the internal structure of the siphons is also known and highly significant differences in the ctenidia and gut also observed. The absence in these three genera of the cruciform muscle, 
otherwise apparently universally present in the Tellinacea, is very probably associated with the extension of pallial fusion (Type B in Pharus but of unknown type in the Novaculininae), along a greater part of the ventral surface; in the great majority of the Tellinacea fusion is confined to a very small region at the base of the siphons where the cruciform muscle acts as a tie for the elongate siphons (Yonge, 1949).

Elongation of the shell in a manner superficially very similar to what occurs in the Solenacea seems to have occurred several times in the Tellinacea. It has led to the appearance of Tagelus (with no ventral mantle fusion but with a cruciform muscle), of Solecurtus (with ventral mantle fusion but involving only the inner mantle folds i.e. Type A, and with a cruciform muscle) and of Pharus- and also probably of the separate group of the Novaculininae- (with more intimate ventral fusion and without a cruciform muscle). The major external difference of these elongate genera from the Solenacea is the approximately central position of the hinge and ligament, the mantle/shell having extended both anteriorly and posteriorly and not solely posteriorly. In the case of Tagelus the habits are also somewhat different, species of this genus occupy semi-permanent vertical burrows in mud. Species of Solecurtus live in deeper water and probably do not burrow deeply or perhaps even very quickly. The habits of the Novaculininae are uncertain but in Pharus they do resemble those of the Solenacea, living in shallow water and burrowing vertically both deeply and with great speed. An important difference may be their need, as deposit feeders, for silty conditions not present in the exposed habitat of most members of the Solenacea. In European waters Solen tends to occupy the environment favoured by Tagelus elsewhere.

\section{SUMMARY}

Pharus legumen (L.), a little-known member of the British marine fauna, is confined to the south-west and to the coasts of Wales. It inhabits a restricted zone on the margin of the lower shore and the shallow sublittoral where some silt is present.

Both in the elongation of the shell and in the habit of vertical burrowing, $P$. legumen resembles members of the Solenacea, i.e. species of Ensis and Solen.

Following description of this species with an account of the pallial structures, organs in the mantle cavity, nature of the ciliary currents on the mantle and the ctenidia, and the course of the alimentary canal, reason is given for the transference of Pharus legumen to the Tellinacea.

Major evidence for this decision comes from the separation of the siphons which are composed exclusively of the inner folds of the mantle margin and have the highly characteristic internal structure of those of the Tellinacea, the absence on the ctenidia of dorsal oralward currents and of the small frontal 
cilia, both characteristic of the Solenacea, and finally from the nature of the stomach with its small postero-dorsal caecum and the deep penetration into the foot of the mid-gut.

The major difference from the Tellinacea generally is the absence of a cruciform muscle but this may be associated with the extensive ventral fusion of the mantle margins, not found in genera with a cruciform muscle with the exception of Solecurtus where it is less extensive and not so intimate (of Type A instead of Type B) as it is in Pharus legumen.

\section{REFERENCES}

Atkins, D., 1936. On the ciliary mechanisms and interrelationships of lamellibranchs. Part I. Quart. F. micr. Sci., Vol. 79, pp. I8I-308.

- I937a. On the ciliary mechanisms and interrelationships of lamellibranchs. Part II. Quart. F. micr. Sci., Vol. 79, pp. 339-73.

- 1937b. On the ciliary mechanisms and interrelationships of lamillibranchs. Part III. Quart. F. micr. Sci., Vol. 79, pp. 375-421.

Bloomer, H. H., I903. Classification of the British species of the genus Solen. f. Malacol., Vol. ro, pp. 4I-3.

Chapman, G. \& Newell, G. E., 1956. The rôle of the body fluid in the movement of soft-bodied invertebrates. II. The extension of the siphons of Mya arenaria L. and Scrobicularia plana (da Costa). Proc. Roy. Soc., B, Vol. I45, pp. 564-80.

Deshayes, G. H. I845-48. Histoire naturelle des Mollusques. I. Mollusques acéphalés. Exploration scientifique de l'Algérie, 1840-42. Sciences Physiques, Zoologie. Paris.

Forbes, E. \& Hanley, S., 1953. A History of British Mollusca, Vol. I. London: Van Voorst.

Fraenkel, G., 1927. Die Grabbewegung der Soleniden. Z. vergl. Physiol., Bd. 6, pp. $167-220$.

Grosh, E., I920. Taxonomic studies on the soft parts of the Solenidae. Rec. Indian Mus., Vol. 19, pp. 47-78.

GrAHAM, A., I93I. On the morphology, feeding mechanisms, and digestion of Ensis siliqua (Schumacher). Trans. roy. Soc. Edinb., Vol. 56, pp. 725-51.

- I934a. The cruciform muscle of lamellibranchs. Proc. roy. Soc. Edinb., Vol. 54, pp. $17-30$.

- $1934 b$. The structure and relationships of lamellibranchs possessing a cruciform muscle. Proc. roy. Soc. Edinb., Vol. 54, pp. 158-87.

Hoffmann, F., I9I4. Beiträge zur Anatomie und Histologie von Tagelus dombeyi (Lamarck). Fena Z. Naturw., Vol. 52, pp. 52I-6I.

JefFreYs, G., 1865. British Conchology, Vol. 3. London: Van Voorst.

OWEN, G., 1958. Shell form, pallial attachment and the ligament in the Bivalvia. Proc. zool. Soc. Lond., Vol. I31, pp. 637-648.

- 1959. Observations on the Solenacea with reasons for excluding the family Glaucomyidae. Phil. Trans. B, Vol. 242, pp. 59-97.

Rawitz, B., 1892. Der Mantelrand der Acephalen. Dritter Teil. Fena Z. Naturw., Bd. 27 , pp. I-232.

Ridewood, W. G., I903. On the structure of the gills of the Lamellibranchia. Phil. Trans. B, Vol. I95, pp. I47-284.

Roscoff, I95I. Inventaire de la Faune Marine de Roscoff. Mollusques. Trav. Sta. biol. Roscoff, Suppl. 5. 
Thiele, J., I935. Handbuch der systematischen Weichtierkunde. Dritter Teil. Classis Bivalvia. Jena: G. Fischer.

Trueman, E. R., I949. The ligament of Tellina tenuis. Proc. zool. Soc. Lond., Vol. I I9, pp. $719-42$.

1953. The structure of the ligament of the Semelidae. Proc. malacol. Soc. Lond., Vol. 30, pp. 30-6.

YoNGE, C. M. 1949. On the structure and adaptations of the Tellinacea, depositfeeding Eulamellibranchia. Phil. Trans. B, Vol. 234, pp. 29-76.

- 1952. Studies on Pacific coast Mollusks. IV. Observations on Siliqua patula and on evolution within the Solenidae. Univ. Calif. Publ. Zoöl., Vol. 55, pp. $42 \mathrm{I}-38$.

— 1957. Mantle fusion in the Lamellibranchia. Pubbl. staz. zool. Napoli, Vol. 29, pp. I5I-7I. 